\title{
Insurer denies coverage for fertility doctor facing lawsuit
}

A

Canadian fertility doctor who is being sued by an American egg donor has been denied insurance coverage because the suit alleges he has contravened the Assisted Human Reproduction Act.

The egg donor - Kylee Gilman, then of Jacksonville, Florida - alleges she had a stroke in November 2011, one day after 45 eggs were removed from her ovaries at the CReATe clinic in Toronto, Ontario. She is suing Dr. Edward Ryan of the Toronto West Fertility Center, a satellite of CReATe, alleging that he stimulated too many eggs. She also claims that, once she returned home and began to feel ill, Ryan gave her bad medical advice. Furthermore, alleges Gilman, Ryan's business model, which involves allowing patients to use paid donors supplied through US-based agencies, was explicitly designed to circumvent Canadian law.

This last unproven allegation has prompted his insurer, Elliott Special Risks, to deny Ryan legal protection. (Because American donors are nonresident patients, doctors caring for them are not covered by the Canadian Medical Protective Association.) The insurer informed Ryan in a letter dated June 18, 2013 that, due to an exclusion in the policy that comes into effect when a law is violated, "based on the allegations in the Complaint and information obtained to date, we regret that the Policy provides no coverage for any of the claims set out in the proceeding, and we have no duty to defend Dr. Ryan."

He is being defended, instead, by an attorney in Florida, though he intends to challenge Elliott Special Risks. The insurer's president, Mario Sousa, declined comment, saying it is company policy not to discuss situations pertaining to their clients.

According to the Assisted Human Reproduction Act, it is illegal to purchase human eggs in Canada. As a consequence, many Canadians have turned to US egg donor agencies, which arrange for American donors to fly into Canada,

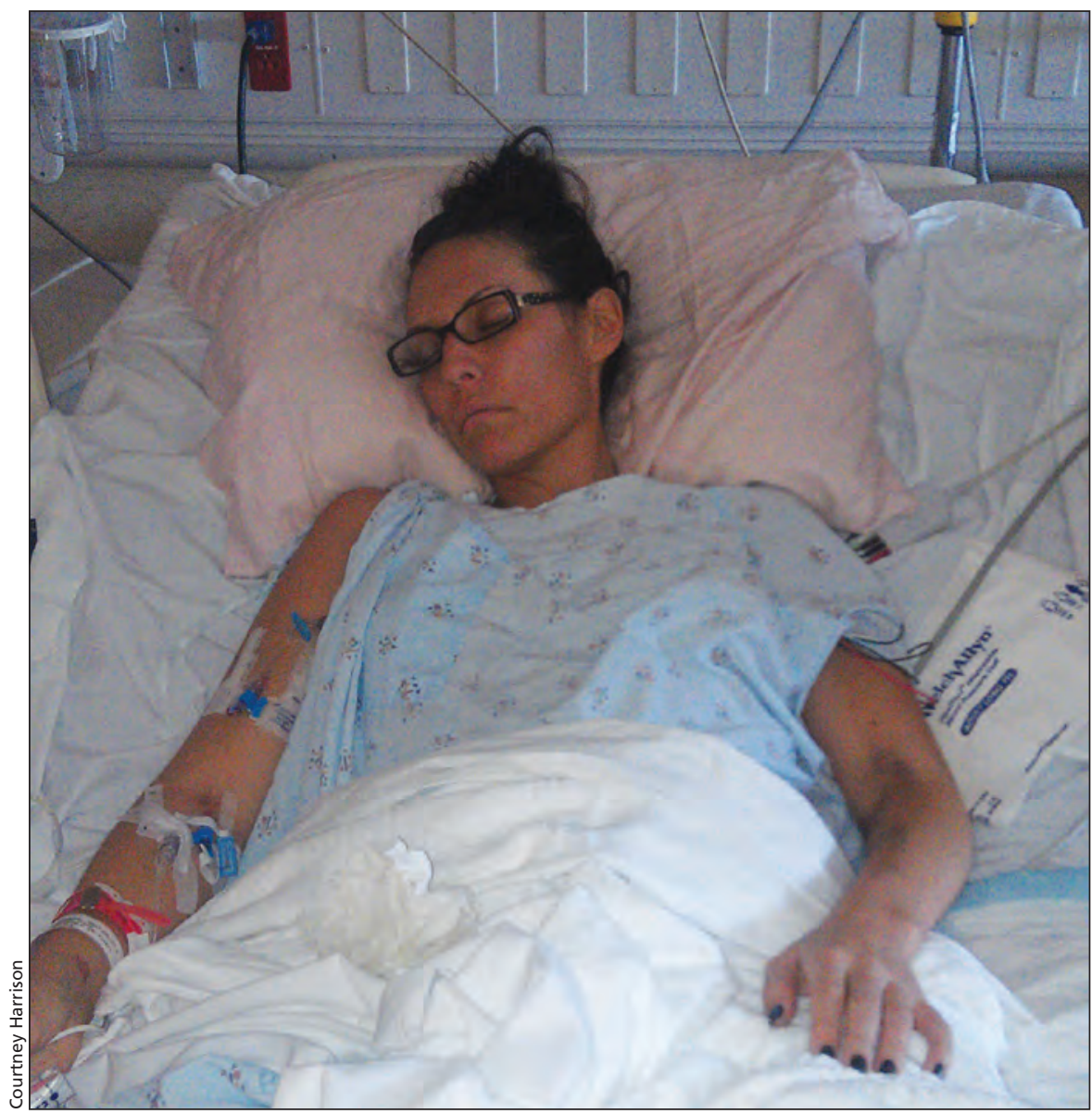

US resident Kylee Gilman alleges she had a stroke a day after 45 eggs were removed from her ovaries at an Ontario fertility clinic.

donate at Canadian clinics and then be paid outside the country. This was the case with Gilman. While recuperating in a Florida hospital, she received US\$5500 from Giving Hope Inc, an agency with headquarters in Dallas, Texas. It is estimated that a few hundred such donations take place every year.

Despite the popularity of the practice, Health Canada has never clarified whether it's legal to use foreign brokers to exchange money outside the country for eggs retrieved locally. The issue has been hotly debated ever since the Assisted Human Reproduction Act was passed in 2004. "It would be very nice if Health Canada would make a clear statement," says Dr. Matt Gysler, president of the Canadian Fertility and
Andrology Society. "Tell us in black and white, in simple language, what it is we can do and can't do."

In the absence of clarity, individual doctors have been left to rely on the interpretations of individual lawyers. According to Toronto fertility lawyer Sherry Levitan, Dr. Ryan did nothing wrong. "He did not act outside of the law," she says. "He did not purchase the eggs."

But legal interpretations differ. "My lawyer says that any transaction performed in Canada needs to abide by Canadian law," says Gysler, who is medical director of the ISIS Regional Fertility Centre in Mississauga, Ont. As a consequence, his clinic does not work with patients who pay egg donors through foreign agencies. 
The insurer's action is bound to have a chilling effect on physicians doing this work, says Colleen Flood, Canada Research Chair in Health Law and Policy at the University of Toronto. This in turn will make it even more difficult for families who want to use donors, says Kelly Jordan, a Toronto fertility lawyer.

The lawsuit was filed in March in Florida. Despite signed agreements between Gilman and both the Toronto West Fertility Centre and CReATe, which stipulate that any disputes must be settled in Ontario, Gilman's lawyer,
Rufus Pennington, is arguing that the case should be heard in Florida. By coincidence, Ryan travelled to Florida for a holiday on the same day Gilman returned home after her retrieval. In the hours leading up to her stroke, according to Gilman, Ryan provided medical advice by cellphone to Gilman. "By giving medical advice to his patient while he was physically located within the state of Florida," says Pennington, "Dr. Ryan subjected himself to the jurisdiction of the Florida courts."
According to court filings, Ryan only learned of his insurer's decision not to defend him when he was served with a motion for default for failing to respond to the lawsuit in a timely fashion. The insurer had initially assigned a lawyer to his case but later withdrew him. A Florida judge will now decide whether to set the default aside and allow the case to proceed, as Ryan's lawyer has requested. - Alison Motluk, Toronto, Ont.

CMAJ 2013. DOI:10.1503/cmaj.109-4604

\section{Suicide prevention training saves lives in Nunavut}

$\mathrm{T}$ he evening Junior Kopak finished a two-day workshop on suicideprevention for Inuit youth in Ottawa, Ontario, he saved his first life.

It was a Thursday in March 2012. A friend from Nunavut, visiting Ottawa on a high school trip, met Kopak downtown. Fresh from his Applied Suicide Intervention Skills Training (ASIST) workshop, Kopak noticed his friend was drinking more than usual, and crying. She blamed herself for arguing with two close family members, in separate incidents, shortly before each committed suicide. One hanged herself two years earlier, and the other killed himself six years previously.

Kopak, 20, was alarmed by what his friend said. So he did what ASIST trained him to do. He asked his friend if she was thinking of ending her life.

She told him she planned to kill herself when she arrived back in Nunavut.

Kopak felt overwhelmed. He worried about saying or doing something to inadvertently push his friend over the mental precipice she straddled. But he had already lost too many people he loved to suicide.

So, he followed the steps ASIST lays out. The internationally acclaimed program - developed by the company LivingWorks, based in Calgary, Alberta is designed to help anyone apply mental health first aid by intervening directly to prevent the immediate risk of suicide. The program, which has trained more than a million caregivers and is used in 15 countries around the world, involves

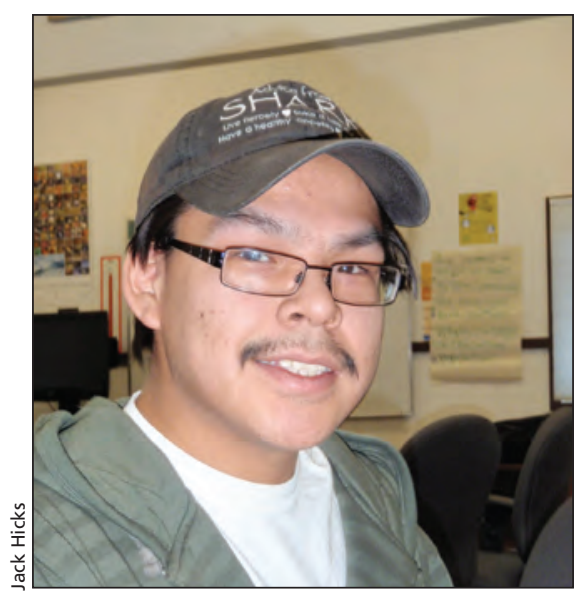

Junior Kopak, who lives in Repulse Bay, Nunavut, used the training he received at an Applied Suicide Intervention Skills Training workshop to save a suicidal friend's life. The course is one of the components of Nunavut's Suicide Prevention Strategy Action plan.

identifying risk, developing a safety plan and directing someone in crisis to further professional mental health support.

The special version of the course that Kopak took, specifically designed for life in Nunavut, is a critical component of the Government of Nunavut's three-year-old Suicide Prevention Strategy and two-year-old Action Plan.

That night in Ottawa, Kopak took a deep breath. Then he dove in to help his friend.

"I listened to her talk," he remembers. "I made sure she was finished talking. Then I said to her, 'I took this course, and I think I can help you.",

The two walked around downtown Ottawa. They talked. Once the young woman was calm, Kopak pulled out his green and white ASIST card.

"Right then and there, she trusted me," Kopak says from Repulse Bay, Nunavut, where he now lives.

With the help of the card, he guided his friend through a process that involves confronting the risk directly. After identifying the ambivalence people who disclose suicidal intentions feel, the intervener helps the person in crisis articulate reasons they have to live, as well as reasons they want to die. After helping his friend appreciate her reasons for living, Kopak suggested resources. They made a safety plan, which involved trying to get counselling and talking to her parents.

Kopak was unable to follow up in person with his friend, as ASIST directs, because he remained in Ottawa while she returned to Nunavut. But he made sure they continued to talk. A year later, she was not only alive, she had a powerful reason to live: a new baby.

Increasingly, First Nations communities with high rates of suicide, like the Siksika Nation in Alberta, are also making ASIST and a shorter version of its suicide awareness training, called safeTALK, a core of their prevention approaches. Siksika's goal is to have someone in every third house on Canada's second-largest reserve trained in safeTALK, says Marsha Wolf Collar, the mental health coordinator with Siksika Health Services.

"If we can have every other home or every third home trained in safeTALK, then that's a protective factor," Wolf Collar says. "It would probably be 